\title{
Treatability studies of hospital wastewaters with AOPs by Taguchi's experimental design
}

\author{
Yonar T. ${ }^{1}$ and Kurt A. ${ }^{2}{ }^{*}$ \\ ${ }^{1}$ Uludag University, Faculty of Engineering, Environmental Engineering, Gorukle Campus, Bursa 16059, Turkey \\ ${ }^{2}$ Central Research Laboratory for the Scientific and Technological Supports, Duzce Universitesi, Konuralp Campus, Duzce 81620, Duzce, \\ Turkey
}

Received: 16/03/2017, Accepted: 26/09/2017, Available online: 23/10/2017

*to whom all correspondence should be addressed: e-mail: kurtayse1987@gmail.com

\begin{abstract}
In this study, it was studied various advanced oxidation treatment processes; Fenton, $\mathrm{UV} / \mathrm{H}_{2} \mathrm{O}_{2}, \mathrm{UV} / \mathrm{O}_{3} / \mathrm{H}_{2} \mathrm{O}_{2}$ for treatability of hospital wastewaters containing antibiotics (cephalosporines). Taguchi's L25 orthogonal array design was applied to design of advanced oxidation processes, for simplification of the analysis and calculations. 95,7\%, 90,65\%, 91,8\% COD and 55,86\%, $60,83 \%, 70,8 \%$ TOC removal efficiencies were obtained under the best operation conditions for $\mathrm{UV} / \mathrm{H}_{2} \mathrm{O}_{2}$, $\mathrm{UV} / \mathrm{O}_{3} / \mathrm{H}_{2} \mathrm{O}_{2}$ and Fenton processes, respectively. According to the ANOVA results, $\mathrm{pH}$ was of great importance in COD removal for Fenton. For the $\mathrm{UV} / \mathrm{H}_{2} \mathrm{O}_{2}$ processes, $\mathrm{H}_{2} \mathrm{O}_{2}$ has significance in $\mathrm{COD}$ and TOC removals. As for the $\mathrm{O}_{3} / \mathrm{UV} / \mathrm{H}_{2} \mathrm{O}_{2}$ processes, $\mathrm{O}_{3} / \mathrm{UV}$ reaction time was found as an important parameter effecting the removal rates. Also, cephalosporine antibiotic active compounds (cefradine and cefaclor) were degraded completely within minutes for all of the processes. Taguchi's Method was found useful for the environmental applications and simplifications of advanced oxidation processes for treatment of hospital wastewaters and calculations.
\end{abstract}

Keywords: advanced oxidation, ozone, hydrogen peroxide, Fenton, cephalosporine, orthogonal array

\section{Introduction}

Pollutants, effecting natural water sources are changing and increasing rapidly day by day, in terms of quantity and composition. Wastewaters are accepted as the main source of these pollutants which affect environment adversely. They may contain heavy metals, radioactive and toxic substances and pharmaceuticals at high level (Gupta et al., 2009; Kajitvichyanukul and Suntronvipart, 2006). However, analysis and treatment technologies of wastewaters are inadequate.

It is well known that, pharmaceutical pollutants have a major impact on the aquatic environment and human health which are found in wastewaters mostly (Daughton and Ruhoy, 2009). They affect human health and aquatic environment adversely and have toxic and endocrine disrupting properties (Walsh, 2003; Sanderson et al., 2004; Kim and Aga, 2007; de Souza et al., 2009; Yu et al., 2009). Among these endocrine disruptor pharmaceuticals antibiotics are accepted as the most dangerous types, because of the microorganism resistance and bioaccumulation in the environment (Petrovic et al., 2005; Blackwell et al., 2004). They are used highly for protection and treatment of human and animal health and improving agricultural processes (Oberlé et al., 2012).

Synthetic antibiotic compounds attract attention with their widespread use in Turkey and worldwide (Balcıoğlu and Arslan, 1997). In Turkey, human and animal applications of antibiotics are much more higher than in northern European countries. According to the IMS (2013-2014) datas, consumptions of cephalosporins, penicillins and quinolones were found very high in Turkey (IMS, 2013 and IMS, 2014). These antibiotic compounds are excreted into the environment through the metabolism of living organisms and agricultural activities. They contaminate aquatic environment by water and wastewater discharges, mostly.

However, hospital wastewaters contain antibiotics at high rate, particularly. They contain pharmaceuticals, heavy metals, radioactive and toxic substances etc. highly (Gupta et al., 2009; Kajitvichyanukul and Suntronvipart, 2006). They are generally treated with centralized domestic wastewater treatment systems without pretreatment processes (Santos et al., 2013; Verlicchi et al., 2010; Thomas et al., 2007). Unfortunately, conventional treatment plants for treatment of these compounds are inadequate in terms of efficiency (Kim and Aga, 2007; Sukul and Spiteller, 2007). Advanced treatment processes such as carbon adsorption, advanced oxidation processes (AOPs), modern pressure-driven membrane processes with reverse osmosis or nanofiltration are recommended for the removal of antibiotics and other pharmaceuticals from wastewaters, instead of conventional treatment methods (Balcioğlu and Arslan, 1997). 
Some countries such as China and Japan treat hospital wastewaters on-site by conventional wastewater treatment plants or membrane bioreactors against the pathogen risks (Liu et al., 2010; Pauwels and Verstraete, 2006). In Europe: Marienhospital Gelsenkirchen and Waldbrol (Germany), Isala clinics in Zwolle (The Netherlands), Cantonal Hospital of Baden (Switzerland) (Pills Project, 2012), a hospital in loannina (Greece) (Kosma et al., 2010) and Herlev hospital (Denmark) (Nielsen et al., 2013) treat wastewaters seperately for the removal of pharmaceuticals. Advanced oxidation processes (AOPs) are promising alternative methods for treatment of hospital wastewaters because of their efficiency and cheapness (Wols and Hofman-Caris, 2012; Sirés and Brillas, 2012).

For this reason, treatability of hospital wastewaters containing antibiotics were investigated by advanced oxidation processes, in this study. Also, Taguchi's L25 orthogonal array design was applied to design of advanced oxidation processes for simplifications of the analysis. Three different generations (1st, 2nd and 3rd) of cephalosporin antibiotics: cefaclor, cephradine and cefoperazone were chosen to investigate in hospital wastewater.

\section{Experimental}

\subsection{Chemicals and standards}

Antibiotic standards used in this study are, cephradine (European Pharmacopoeia Reference Standard, C090000), cefaclor (Fluka, 72579-50MG) and cefoperazone (Sigma-Aldrich, C4292-1G). Methanol (gradient grade for HPLC, Sigma-Aldrich, 34885-2,5L-R) and formic asid (Sigma-Aldrich) were the purity of $\geq$ $99.9 \%$ and $98-100 \%$, respectively, which were used in mobile phase for the HPLC analysis.

\subsection{Wastewater characteristics}

Composite wastewater samples were taken from a hospital discharge, (Duzce University Research Hospital, Turkey) for one year, monthly.

Table 1. The physical and chemical characteristics of hospital wastewater

\begin{tabular}{ccc}
\hline Parameter & Unit & Value \\
\hline $\mathrm{pH}$ & - & $9,1 \pm 0,1$ \\
Conductivity & $\mathrm{Mg} \mathrm{cm}^{-1}$ & $1464,5 \pm 1,2$ \\
DO $^{*}$ & $\mathrm{mg} \mathrm{l}^{-1}$ & $2,33 \pm 0,02$ \\
BOD $^{*}$ & $\mathrm{mg} \mathrm{l}^{-1}$ & $155,5 \pm 2,3$ \\
COD $^{*}$ & $\mathrm{mg} \mathrm{l}^{-1}$ & $290,5 \pm 3,1$ \\
TOC $^{*}$ & $\mathrm{mg} \mathrm{l}^{-1}$ & $77,105 \pm 0,8$ \\
DOC $^{*}$ & $\mathrm{mg} \mathrm{l}^{-1}$ & $66,84 \pm 0,9$ \\
SS $^{*}$ & $\mathrm{mgl}^{-1}$ & $80 \pm 1,7$ \\
TKN & $\mathrm{mg} \mathrm{l}^{-1}$ & $226,7 \pm 2,3$ \\
Total Phosphorous & $\mathrm{mg} \mathrm{l}^{-1}$ & $4,41 \pm 0,3$ \\
\hline
\end{tabular}

*COD: Chemical oxygen demand; TOC: Total organic carbon; BOD $_{5}$ : 5-day biochemical oxygen demand; DOC: Dissolved organic carbon; SS: Suspended solids; TKN: Total kjeldahl nitrogen; DO: Dissolved oxygen

Samples were stored in opaque PE containers at $4{ }^{\circ} \mathrm{C}$ to prevent degradation. Cefradine concentration range was found between $0,09-0,28 \mu \mathrm{g} \mathrm{I}^{-1}$ and cefaclor was 0-0,039 $\mathrm{mg} \mathrm{l}^{-1}$, while cefoperazone could not be detected. The physical and chemical characteristics of wastewater were given in Table 1.

\subsection{Analytical methods}

TOC and DOC measurements were made by using TOC-L analyser (Shimadzu) and ASI-L autosampler (Shimadzu). Conductivity, $\mathrm{pH}$ and $\mathrm{DO}$ measurements were made by using multimeter (Hach-Lange, HQ40D). Analytic determination of antibiotics in hospital wastewater were carried out by HPLC-PDA detector (High performanced liquid chromatography - photo diode array detector) (Shimadzu). Inertsil C-18 column (150 x $4.6 \mathrm{~mm} ; 5 \mathrm{~mm}$ ) was used as mobile phase column. Mobile phase solution was prepared by water including 0,1\% formic asid and methanol, $\mathrm{MeOH}: \mathrm{H} 2 \mathrm{O}=40: 60(\mathrm{v} / \mathrm{v})$. Analysis were carried out at isocratic mode. Flow rate was chosen as $0,5 \mathrm{ml}$ min-1. PDA detector wavelength range was selected as 254 and $270 \mathrm{~nm}$. Column oven temperature was $35^{\circ} \mathrm{C}$. $6 \mathrm{ml}$ solid-phase extraction cartridges (SUPELCO, Supelclean ENVI-8), Na2EDTA (Disodium ethylenediaminetetraacetate dihydrate) (Merck) and $\mathrm{HCl}$ (EMSURE) were used for solid phase extraction.

$\mathrm{MnO}_{2}$ powder (Merck) was used to remove residual $\mathrm{H}_{2} \mathrm{O}_{2}$, by controlling with test strips (Merck). To remove $\mathrm{Fe}(\mathrm{OH})_{3}$ and $\mathrm{MnO}_{2}$, supernatants were filtered through $0,45 \mu \mathrm{m}$ milipore membranes. $\mathrm{BOD}_{5}, \mathrm{COD}, \mathrm{SS}$, total phosphorous, total nitrogen and $\mathrm{pH}$ were measured according to the Standard Methods (APHA, 1998). All of the measurements were carried out in triplicate.

\subsection{Advanced oxidation processes}

Photochemical oxidation system, used for the $\mathrm{H}_{2} \mathrm{O}_{2} / \mathrm{UV}$ (hydrogen peroxide/ultraviole), and $\mathrm{H}_{2} \mathrm{O}_{2} / \mathrm{O}_{3} / \mathrm{UV}$ (hydrogen peroxide/ozonation/ultraviole) processes was designed and manufactured to be used as both batch and constant. Experiments were carried out in constant mode. Low-pressure TUV-8 model UV lamp was used (Philips) in the reactor. Maximum wavelength of the lamp was $254 \mathrm{~nm}$. It was placed into the reactor $(2,8 \mathrm{~L})$ in pure quartz cover ( $40 \mathrm{~cm}$ length and $4 \mathrm{~cm}$ diameter). The reactor body was made of 316-Ti stainless steel and inner diameter was $41 \mathrm{~cm}$ by $9.8 \mathrm{~cm}$ length.

Opal 200 model ozone generator was used for the ozonation processes with ozone production capacity of $200 \mathrm{mg} \mathrm{hr}^{-1}$ by airflow. Ozonation experiments were made by addition of wastewater into the glassware $(0,5 \mathrm{~L})$. Flow rate of the generator was fixed at $60 \mathrm{~L} \mathrm{hr}^{-1}$ hourly for all of the experimental works. All connections were made by Teflon tubing.

\subsection{Taguchi's Experimental Design}

Taguchi's method is a robust statistical tool, capable of finding out significant parameters for ideal processes/experiments from many other parameters (Chiang and Hsieh, 2009). The method include orthogonal arrays and allow studying with minimum number of experiments by using several factors (Sharma et al., 2005). Also, it reduce the variability of the process, 
and consequently, reduce the operating costs (Barros et al., 1995). In this study, "Taguchi's Method" statistical principles were applied to design and optimization of parameters effecting advanced oxidation processes. Experimental designs were made according to the
Taguchi's L25 orthogonal array design. "Minitab 17" statistical analysis program was used for the data input and design. Taguchi's L25 orthogonal design parameters for AOPs were shown in Table 2.

Table 2. Factors and levels of the processes according to Taguchi's L25 orthogonal design

\begin{tabular}{clccccc}
\hline Process & Factor & Level 1 & Level 2 & Level 3 & Level 4 & Level 5 \\
\hline \multirow{4}{*}{ Fenton } & $\mathrm{A}: \mathrm{pH}$ & 2 & 3 & 4 & 5 & 6 \\
\cline { 2 - 7 } & $\mathrm{B}: \mathrm{Fe}^{2+}\left(\mathrm{mg} \mathrm{l}^{-1}\right)$ & 25 & 50 & 75 & 100 & 125 \\
\cline { 2 - 7 } & $\mathrm{C}: \mathrm{H}_{2} \mathrm{O}_{2}\left(\mathrm{mg} \mathrm{l}^{-1}\right)$ & 25 & 50 & 75 & 100 & 125 \\
\hline \multirow{2}{*}{$\mathrm{UV} / \mathrm{H}_{2} \mathrm{O}_{2}$} & $\mathrm{E}: \mathrm{UV}(\mathrm{min})$ & 30 & 60 & 90 & 120 & 150 \\
\cline { 2 - 7 } & $\mathrm{C}: \mathrm{H}_{2} \mathrm{O}_{2}\left(\mathrm{mg} \mathrm{l}^{-1}\right)$ & 25 & 50 & 75 & 100 & 125 \\
\hline \multirow{2}{*}{$\mathrm{UV} / \mathrm{O}_{3} / \mathrm{H}_{2} \mathrm{O}_{2}$} & $\mathrm{~F}: \mathrm{UV} / \mathrm{O}_{3}(\mathrm{~min})$ & 30 & 60 & 90 & 120 & 150 \\
\cline { 2 - 7 } & $\mathrm{C}: \mathrm{H}_{2} \mathrm{O}_{2}\left(\mathrm{mg} \mathrm{l}^{-1}\right)$ & 25 & 50 & 75 & 100 & 125 \\
\hline
\end{tabular}

\section{Results and discussion}

Cephalosporine antibiotic active compounds (cefradine and cefaclor) were degraded completely within minutes for all of the advanced oxidation processes. COD and TOC removals were interpretated by Main Effects Plots for the AOPs.

\section{Fenton}

Main Effects Plots for COD and TOC were given in figure 1. and figure 2. for Fenton. Depending on the increase in $\mathrm{pH}, \mathrm{COD}$ removals decreased first and then increased suddenly, later decreased again, and finally rose. It was resulted from the changes in COD removal efficiencies that fenton reactions are very sensitive to changes in $\mathrm{pH}$. Depending on the changes in $\mathrm{H}_{2} \mathrm{O}_{2}$ concentration, $\mathrm{COD}$ removal efficiencies were decreased with the $\mathrm{H}_{2} \mathrm{O}_{2}$ addition. When the concentration reached to $100 \mathrm{mg} \mathrm{l}^{-1}$, COD removal rates rose significantly and then dropped again. Changes in $\mathrm{Fe}^{+2}$ concentration did not effect the COD removals significantly, while a slight increase was observed in removals at $50 \mathrm{ppm}$.

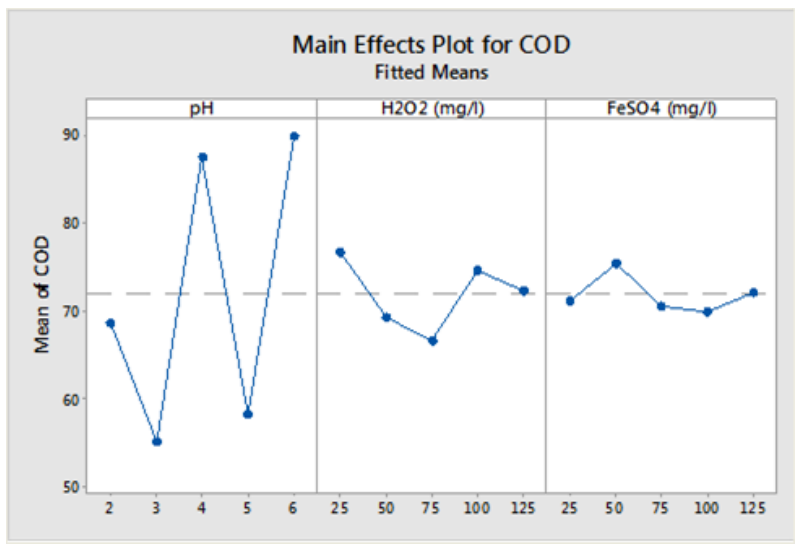

Figure 1. Main Effects Plot for COD for the Fenton

TOC removal rates showed a sudden increase when $\mathrm{pH}$ rose to 5 and then decreased again. TOC removals were effected positively from the increase in peroxide concentration. The removal efficiencies remained constant for 50-75 $\mathrm{mg} \mathrm{l}^{-1}$, then dropped again, and when
$\mathrm{H}_{2} \mathrm{O}_{2}$ concentration reached to $125 \mathrm{mg} \mathrm{l}^{-1}$, efficiency rose suddenly. TOC removals were effected positively from increase in $\mathrm{Fe}^{+2}$ concentration but it was observed a sudden decrease at $125 \mathrm{ppm}$.

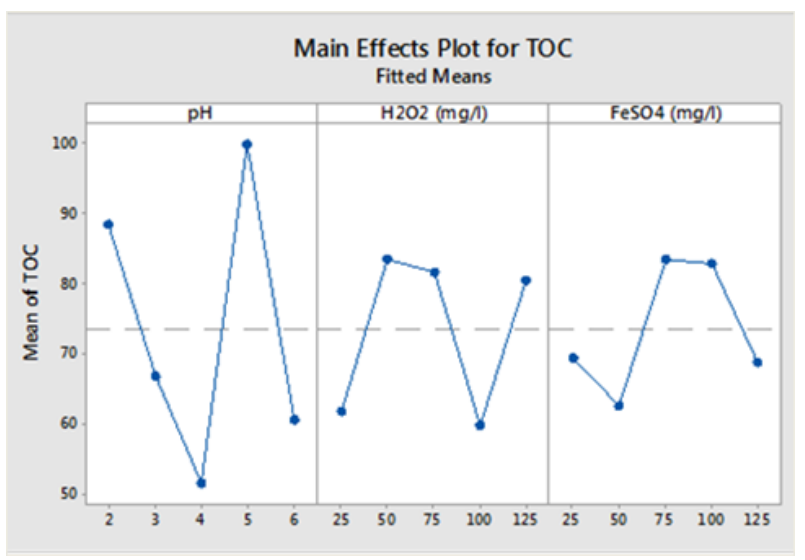

Figure 2. Main Effects Plot for TOC for the Fenton

The changes in COD and TOC removal rates were affected adversely from each other in Fenton reactions. TOC removal rates decreased with COD removal increase, while increased with COD removal decrease.

For the Fenton processes, 91,8\% COD and 70,8\% TOC removal rates were observed as the best results at the conditions of $\mathrm{pH} 4$ with $25 \mathrm{mg} \mathrm{l}^{-1} \mathrm{H}_{2} \mathrm{O}_{2}$ and $75 \mathrm{mg} \mathrm{l}^{-1} \mathrm{FeSO}_{4}$. $63,16 \%$ COD and $75 \%$ TOC degradation were observed at $\mathrm{pH} 6$ with $25 \mathrm{mg} \mathrm{l}^{-1} \mathrm{H}_{2} \mathrm{O}_{2}$ and $125 \mathrm{mg} \mathrm{l}^{-1} \mathrm{FeSO}_{4}$. Furthermore, 91,7\% COD removal was obtained at $\mathrm{pH} 6$ with $125 \mathrm{mg} \mathrm{l}^{-1} \mathrm{H}_{2} \mathrm{O}_{2}$ and $100 \mathrm{mg} \mathrm{l}^{-1} \mathrm{FeSO}_{4}$, and $91,16 \%$ COD degradation was obtained at $\mathrm{pH} 6$ with $25 \mathrm{mg} \mathrm{l}^{-1}$ $\mathrm{H}_{2} \mathrm{O}_{2}$ and $125 \mathrm{mg} \mathrm{l}^{-1} \mathrm{FeSO}_{4}$. Affam and Chaudhuri (2013) investigated fenton oxidation of amoxicillin and cloxacillin aqueous solution $\left(\mathrm{H}_{2} \mathrm{O}_{2} / \mathrm{COD}: 2, \mathrm{H}_{2} \mathrm{O}_{2} / \mathrm{Fe}^{2+}\right.$ : 76 , reaction time: $90 \mathrm{~min}$ and $\mathrm{pH} 3$ ) and they found removal efficiencies \% 78,98 and 72,96 for COD and TOC, respectively.

$\mathrm{UV} / \mathrm{H}_{2} \mathrm{O}_{2}$

Main Effects Plots for COD and TOC were given in figure 3. and figure 4. for the $\mathrm{UV} / \mathrm{H}_{2} \mathrm{O}_{2}$ processes, respectively. Depending on the increase in UV irradiation time, the 
COD removal efficiencies decreased first, eventually reached to the optimum after $90 \mathrm{~min}$ and then dropped again. Depending on the changes in $\mathrm{H}_{2} \mathrm{O}_{2}$ concentration, the removal efficiencies of COD and TOC were constant at 30 and $60 \mathrm{~min}$, while reached to optimum after $90 \mathrm{~min}$ of irradiation, then started to decrease. TOC was reduced by additon of $\mathrm{H}_{2} \mathrm{O}_{2}$ first, then increased when it reached to $100 \mathrm{mg} \mathrm{l}^{-1}$, finally dropped again.

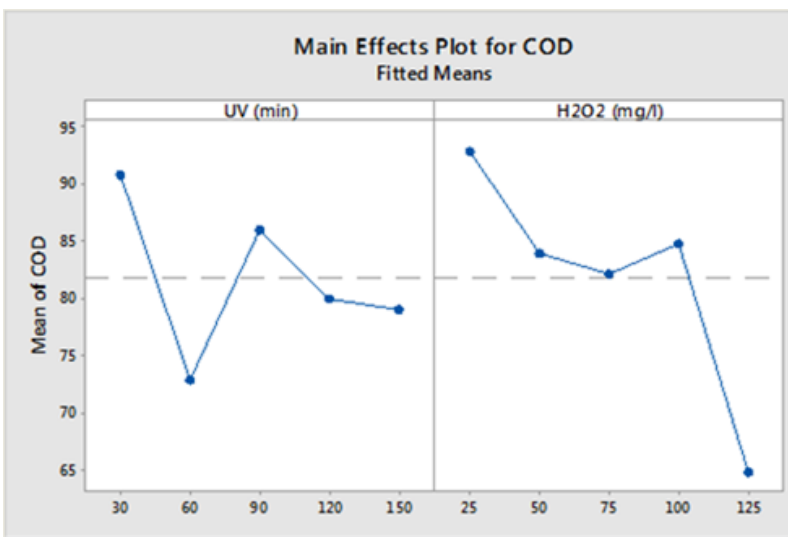

Figure 3. Main Effects Plot for COD for the UV/ $\mathrm{H}_{2} \mathrm{O}_{2}$

At UV $/ \mathrm{H}_{2} \mathrm{O}_{2}$ processes $91,8 \% \mathrm{COD}$ and $91 \%$ TOC removals were obtained as the best results after $30 \mathrm{~min}$ UV reaction with $125 \mathrm{mg} \mathrm{l}^{-1} \mathrm{H}_{2} \mathrm{O}_{2}$. 91,3\% COD and 84,7\% TOC removals were observed after 30 min with $75 \mathrm{mg} \mathrm{l}^{-1} \mathrm{H}_{2} \mathrm{O}_{2}$ and $90 \%$ COD and $84,7 \%$ TOC removals were obtained after 30 min with $100 \mathrm{mg} \mathrm{l}^{-1} \mathrm{H}_{2} \mathrm{O}_{2}$. Jung et al., (2012) investigated oxidation of amoxicillin by $\mathrm{UV} / \mathrm{H}_{2} \mathrm{O}_{2}$ and they found low mineralization degree and observed maximum $50 \%$ TOC removal after $80 \mathrm{~min}$.

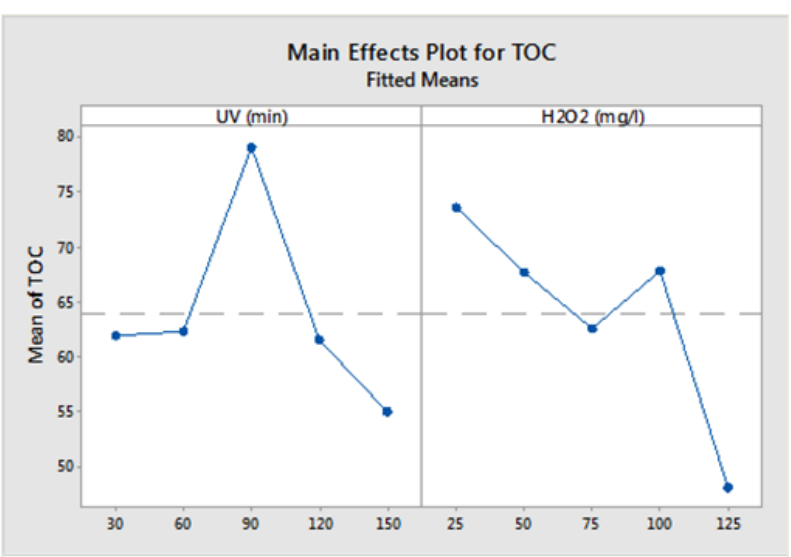

Figure 4. Main Effects Plot for TOC for the UV/ $\mathrm{H}_{2} \mathrm{O}_{2}$

\section{$\mathrm{UV} / \mathrm{H}_{2} \mathrm{O}_{2} / \mathrm{O}_{3}$}

Main Effects Plots for COD and TOC were given in figure 5 and figure 6 for the $\mathrm{UV} / \mathrm{H}_{2} \mathrm{O}_{2} / \mathrm{O}_{3}$ processes respectively. The removal efficiencies of COD and TOC decreased by the addition of $\mathrm{H}_{2} \mathrm{O}_{2}$. When the concentration reached to $100 \mathrm{mg} \mathrm{l}^{-1}$, efficiencies rose significantly, then fell again and finally remained stable. Depending on the increase in $\mathrm{UV} / \mathrm{O}_{3}$ reaction time, the $\mathrm{COD}$ and $\mathrm{TOC}$ removal efficiencies decreased first, eventually reached to the optimum after $90 \mathrm{~min}$ and then dropped again.
For the $\mathrm{UV} / \mathrm{O}_{3} / \mathrm{H}_{2} \mathrm{O}_{2}$ processes, $89 \% \mathrm{COD}$ and $64,5 \%$ TOC removal rates were observed after 90 min reaction with $25 \mathrm{mg} \mathrm{l}^{-1} \mathrm{H}_{2} \mathrm{O}_{2}$ as the best results. At the same processes, $90,65 \%$ COD and $60,83 \%$ TOC removal rates were observed after 120 min with $75 \mathrm{mg} \mathrm{l}^{-1} \mathrm{H}_{2} \mathrm{O}_{2}$, while $87,6 \%$ COD and $65,6 \%$ TOC removals were obtained after 60 min with $25 \mathrm{mg} \mathrm{l}^{-1} \mathrm{H}_{2} \mathrm{O}_{2}$.

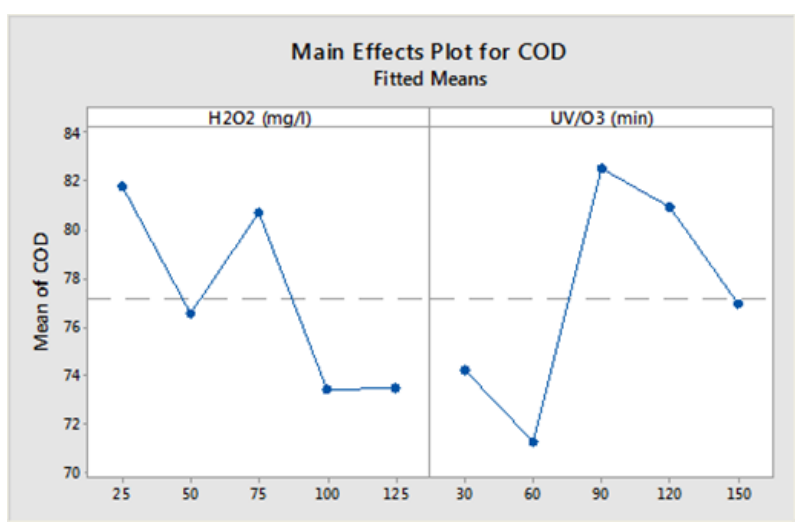

Figure 5. Main Effects Plot for $\mathrm{COD}$ for the $\mathrm{UV} / \mathrm{H}_{2} \mathrm{O}_{2} / \mathrm{O}_{3}$

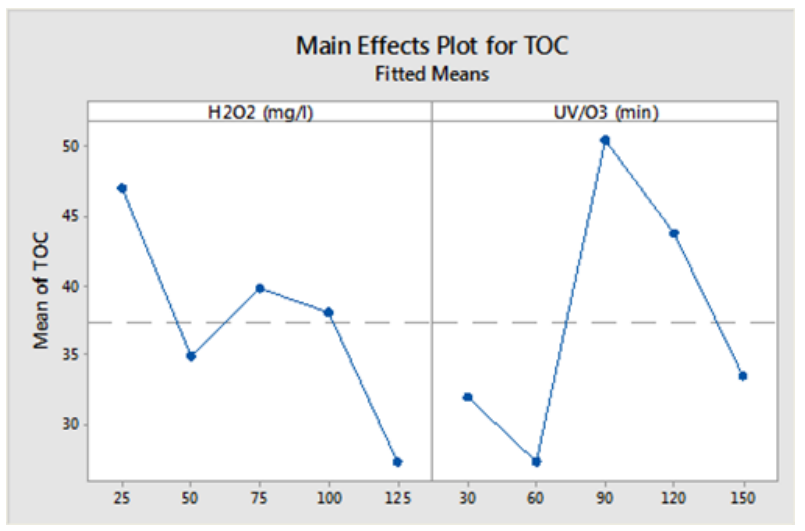

Figure 6. Main Effects Plot for TOC for the UV/ $\mathrm{H}_{2} \mathrm{O}_{2} / \mathrm{O}_{3}$

\section{Analysis of variance (ANOVA)}

Analysis of variance (ANOVA) was applied, for evaluating significance of the parameters (Rosa et al., 2009). ANOVA analysis was shown in Table 3 for treatability of hospital wastewater by the advanced oxidation processes. According to the results, variance with $95 \%$ trust, and $\mathrm{p}$ value lower than $5 \%$; $\mathrm{pH}(\mathrm{F}=15.12, \mathrm{P}$-value $=0 \%$ for $\mathrm{COD}$ and $\mathrm{F}=1.77, \mathrm{P}$-value $=0.186 \%$ for TOC) has significance in COD and TOC removals for Fenton processes. $\mathrm{H}_{2} \mathrm{O}_{2}(\mathrm{~F}=$ 1.165, P-value $=0.365 \%$ ) was found important for TOC removals for the same processes. For the $\mathrm{UV} / \mathrm{H}_{2} \mathrm{O}_{2}$ processes, $\mathrm{H}_{2} \mathrm{O}_{2}(\mathrm{~F}=1.722$, $\mathrm{P}$-value $=0.185 \%$ for $\mathrm{COD}$ and $\mathrm{F}=1.433, \mathrm{P}$-value $=0.186 \%$ for $\mathrm{TOC}$ ) has significance in COD and TOC removals and UV (F=0.901, $P$ value $=0.482 \%$ ) was found important for TOC removals for the same process. As for the $\mathrm{O}_{3} / \mathrm{UV} / \mathrm{H}_{2} \mathrm{O}_{2}$ processes, $\mathrm{O}_{3} / \mathrm{UV}$ reaction time $(\mathrm{F}=1.490, \mathrm{P}$-value $=0.243 \%$ for $\mathrm{COD}$ and $F=1.137$, $P$-value $=0.368 \%$ for TOC) was found as an important parameter effecting the removal rates. 


\section{Conclusions}

In this study, it was studied advanced oxidation treatment processes for treatability of hospital wastewaters containing antibiotics. Taguchi's L25 orthogonal array design was applied to design of processes. The main results were given below:

- The changes in COD and TOC removal rates were affected adversely from each other in Fenton reactions. TOC removal rates decreased with COD removal increase, while TOC removals improved with COD removal decrease. At $\mathrm{UV} / \mathrm{H}_{2} \mathrm{O}_{2}$ processes depending on the changes in $\mathrm{H}_{2} \mathrm{O}_{2}$ concentration, the removal efficiencies of COD and TOC removal rates were constant at 30 and $60 \mathrm{~min}$, while removals reached to optimum after $90 \mathrm{~min}$ of irradiation and then started to decrease. As for the $\mathrm{O}_{3} / \mathrm{UV} / \mathrm{H}_{2} \mathrm{O}_{2}$ porcesses, the removal efficiencies of COD and TOC decreased by the addition of $\mathrm{H}_{2} \mathrm{O}_{2}$ up to 100 $\mathrm{mg} \mathrm{l}^{-1}$. Depending on the increase in $\mathrm{UV} / \mathrm{O}_{3}$ reaction time, COD and TOC removal rates decreased first, eventually reached to the optimum after $90 \mathrm{~min}$ and then dropped again.

- $\quad$ For the Fenton processes, $91,8 \%$ COD and $70,8 \%$ TOC removal rates were observed as the best results at $\mathrm{pH} 4$, with $25 \mathrm{mg} \mathrm{l}^{-1} \mathrm{H}_{2} \mathrm{O}_{2}$ and $75 \mathrm{mg} \mathrm{l}^{-1}$ $\mathrm{FeSO}_{4}$. At UV/ $\mathrm{H}_{2} \mathrm{O}_{2}$ processes, $91,8 \% \mathrm{COD}$ and 91\% TOC removals were obtained as the best results after 30 min UV degradation with 125 $\mathrm{mg} \mathrm{l}^{-1} \mathrm{H}_{2} \mathrm{O}_{2}$. As for the $\mathrm{UV} / \mathrm{O}_{3} / \mathrm{H}_{2} \mathrm{O}_{2}$ processes, $89 \%$ COD and $64,5 \%$ TOC removal rates were observed after 90 min reaction with $25 \mathrm{mg} \mathrm{l}^{-1}$ $\mathrm{H}_{2} \mathrm{O}_{2}$ as the best results.

- Cephalosporine antibiotic active compounds (cefradine and cefaclor) were degraded completely within minutes for all of the processes.

- According to the ANOVA results, $\mathrm{pH}$ was of great importance in COD removal for the Fenton processes. For the $\mathrm{UV} / \mathrm{H}_{2} \mathrm{O}_{2}$ processes, $\mathrm{H}_{2} \mathrm{O}_{2}$ has significance in COD and TOC removals. As for the $\mathrm{O}_{3} / \mathrm{UV} / \mathrm{H}_{2} \mathrm{O}_{2}$ processes, $\mathrm{O}_{3} / \mathrm{UV}$ reaction time was found as an important parameter in terms of efficiency

- Consequently, Taguchi's Method was found useful for environmental applications and simplifications of advanced oxidation processes for treatment of hospital wastewaters and calculations.

Table 3. Analysis of variance for hospital wastewater degradation

\begin{tabular}{|c|c|c|c|c|c|c|c|c|c|c|c|}
\hline & \multirow{2}{*}{ Factors } & \multicolumn{2}{|c|}{ Sum of Squares } & \multicolumn{2}{|c|}{ DF* } & \multicolumn{2}{|c|}{ Mean Sum } & \multicolumn{2}{|c|}{ Fisher Test } & \multicolumn{2}{|c|}{ P-Value* } \\
\hline & & COD & TOC & COD & TOC & COD & TOC & COD & TOC & COD & TOC \\
\hline \multirow{5}{*}{ Fenton } & $\mathrm{H}_{2} \mathrm{O}_{2}$ & 718.134 & 3.767 .18 & 4 & 4 & 179.533 & 941.795 & 0.392 & 1.165 & 0.811 & 0.365 \\
\hline & $\mathrm{FeSO}_{4}$ & 112.244 & 2.166 .36 & 4 & 4 & 28.061 & 541.590 & 0.056 & 0.592 & 0.993 & 0.674 \\
\hline & $\mathrm{pH}$ & 6.078 .09 & 5.111 .13 & 4 & 4 & 1.519 .52 & 1.277 .78 & 15.120 & 1.777 & 0.000 & 0.186 \\
\hline & Error & 2686,7 & 7718 & 12 & 12 & 223,89 & 643,2 & & & & \\
\hline & Total & 29235,2 & 20302 & 24 & 24 & & & & & & \\
\hline \multirow{4}{*}{$\mathrm{UV} / \mathrm{H}_{2} \mathrm{O}_{2}$} & $\mathrm{H}_{2} \mathrm{O}_{2}$ & 2.128 .38 & 1.863 .78 & 4 & 4 & 532.09 & 465.945 & 1.722 & 1.433 & 0.185 & 0.260 \\
\hline & UV & 1.110 .10 & 1.277 .12 & 4 & 4 & 277.52 & 319.280 & 0.771 & 0.901 & 0.557 & 0.482 \\
\hline & Error & 4435,1 & 4741 & 16 & 16 & 277,2 & 296,3 & & & & \\
\hline & Total & 8307,1 & 8367 & 24 & 24 & & & & & & \\
\hline \multirow{4}{*}{$\mathrm{O}_{3} / \mathrm{UV} / \mathrm{H}_{2} \mathrm{O}_{2}$} & $\mathrm{H}_{2} \mathrm{O}_{2}$ & 312.126 & 1.036 .16 & 4 & 4 & 78.031 & 259.041 & 0.987 & 0.600 & 0.437 & 0.667 \\
\hline & $\mathrm{O}_{3} / \mathrm{UV}$ & 434.738 & 1.791 .10 & 4 & 4 & 108.68 & 447.774 & 1.490 & 1.137 & 0.243 & 0.368 \\
\hline & Error & 1146,4 & 6842 & 16 & 16 & 71,65 & 427,6 & & & & \\
\hline & Total & 1893,2 & 9669 & 24 & 24 & & & & & & \\
\hline
\end{tabular}

*DF: Degrees of freedom; P: Probability

\section{References}

APHA (1998), Standard Methods for the Examination of Water and Wastewater, 20th, American Public Health Association, Washington, D.C, USA.

Affama A. C. and Chaudhuria M. (2014), Optimization of Fenton treatment of amoxicillin and cloxacillin antibiotic aqueous solution, Desalination and Water Treatment, 52, 1878-1884.

Balcıoğlu I.A. and Arslan I. (1997), Treatment of textile waste water by heterogenous photocatalytic oxidation processes, Environmental technology, 18, 1053-1059.

Barros N., Bruns R. and Scarminio I. (1995), Otimização e planejamento de Experimentos, Campinas: Editora da Unicamp, 291.

Blackwell P.A., Lützhøft H.C.H., Ma H.P., Halling-Sørensen B., Boxall A.B. and Kay P. (2004), Fast and robust simultaneous determination of three veterinary antibiotics in groundwater and surface water using a tandem solid-phase extraction with high-performance liquid chromatographyUV detection, Journal of Chromatography A, 1045, 111-117.

Chiang Y.M. and Hsieh H.H. (2009), The use of the Taguchi method with grey relational analysis to optimize the thinfilm sputtering process with multiple quality characteristic in color filter manufacturing, Computers and Industrial Engineering, 56, 648-661.

Daughton C.G. and Ruhoy I.S. (2009), Environmental footprint of pharmaceuticals: the significance of factors beyond direct excretion to sewers, Environmental toxicology and chemistry, 28, 2495-2521.

Gupta P., Mathur N., Bhatnagar P., Nagar P. and Srivastava S. (2009), Genotoxicity evaluation of hospital wastewaters, Ecotoxicology and Environmental Safety, 72, 1925-1932. 
IMS. (2013), Intercontinental Medical Statistics, Türkiye Illaç ve Tıbbi Cihaz Kurumu Akılcı İlaç Kullanımı ve İlaç Tedarik Yönetimi Dairesi.

IMS. (2014), Intercontinental Medical Statistics, Türkiye İlaç ve Tıbbi Cihaz Kurumu Akılcı Illaç Kullanımı ve Illaç Tedarik Yönetimi Dairesi.

Kajitvichyanukul P. and Suntronvipart N. (2006), Evaluation of biodegradability and oxidation degree of hospital wastewater using photo-Fenton process as the pretreatment method, Journal of Hazardous Materials, 138, 384-391.

Kim S. and Aga D.S. (2007), Potential ecological and human health impacts of antibiotics and antibiotic-resistant bacteria from wastewater treatment plants, Journal of Toxicology and Environmental Health, Part B, 10, 559-573.

Kosma C.I., Lambropoulou D.A. and Albanis T.A. (2010), Occurrence and removal of PPCPs in municipal and hospital wastewaters in Greece, Journal of Hazardous Materials, 179, 804-817.

Liu Q., Zhou Y., Chen L. and Zheng X. (2010), Application of MBR for hospital wastewater treatment in China, Desalination, 250, 605-608.

Nielsen U., Hastrup C., Klausen M., Pedersen B., Kristensen G., Jansen J., Bak S. and Tuerk J. (2013), Removal of APIs and bacteria from hospital wastewater by $\mathrm{MBR}$ plus $\mathrm{O}_{3}, \mathrm{O}_{3}+$ $\mathrm{H}_{2} \mathrm{O}_{2}, \mathrm{PAC}$ or $\mathrm{ClO}_{2}$, Water Science and Technology, 67, 854-862.

Oberlé K., Capdeville M.J., Berthe T., Budzinski H. and Petit F. (2012), Evidence for a complex relationship between antibiotics and antibiotic-resistant Escherichia coli: from medical center patients to a receiving environment, Environmental science and technology, 46, 1859-1868.

Pauwels B. and Verstraete W. (2006), The treatment of hospital wastewater: an appraisal, Journal of Water and Health, 4, 405-416.

Rosa J.L., Robin A., Silva M., Baldan C.A. and Peres M.P. (2009), Electrodeposition of copper on titanium wires: Taguchi experimental design approach, Journal of Materials Processing Technology, 209, 1181-1188.

Sanderson H., Johnson D.J., Reitsma T., Brain R.A., Wilson C.J. and Solomon K.R. (2004), Ranking and prioritization of environmental risks of pharmaceuticals in surface waters, Regulatory toxicology and pharmacology, 39, 158-183.

Santos L.H., Gros M., Rodriguez-Mozaz S., Delerue-Matos C., Pena A., Barceló D. and Montenegro M.C.B. (2013), Contribution of hospital effluents to the load of pharmaceuticals in urban wastewaters: identification of ecologically relevant pharmaceuticals, Science of the Total Environment, 461, 302-316.

Sharma P., Verma A., Sidhu R. and Pandey O. (2005), Process parameter selection for strontium ferrite sintered magnets using Taguchi L9 orthogonal design, Journal of Materials Processing Technology, 168, 147-151.

Sirés I. and Brillas E. (2012), Remediation of water pollution caused by pharmaceutical residues based on electrochemical separation and degradation technologies: a review, Environment international, 40, 212-229.

Souza S.M.L., Vasconcelos E.C., Dziedzic M. and Oliveira C.M.R. (2009), Environmental risk assessment of antibiotics: an intensive care unit analysis, Chemosphere, 77, 962-967.
Sukul P. and Spiteller M. (2007), Fluoroquinolone antibiotics in the environment, Reviews of environmental contamination and toxicology, Springer, 191, 131-162.

Thomas K.V., Dye C., Schlabach M. and Langford K.H. (2007), Source to sink tracking of selected human pharmaceuticals from two Oslo city hospitals and a wastewater treatment works, Journal of Environmental Monitoring, 9, 1410-1418.

Verlicchi P., Galletti A., Petrovic M. and Barceló D. (2010), Hospital effluents as a source of emerging pollutants: an overview of micropollutants and sustainable treatment options, Journal of Hydrology, 389, 416-428.

Wols B. and Hofman-Caris C. (2012), Review of photochemical reaction constants of organic micropollutants required for UV advanced oxidation processes in water, Water Research, 46, 2815-2827.

Yu D., Yi X., Ma Y., Yin B., Zhuo H., Li J. and Huang Y. (2009), Effects of administration mode of antibiotics on antibiotic resistance of Enterococcus faecalis in aquatic ecosystems, Chemosphere, 76, 915-920. 